\title{
Potential Multimodal Transport in Bangladesh and
} Relative Obstacles

\author{
Md. Mashiur Rahaman ${ }^{1}$ and Khandaker Rasel Hasan ${ }^{2}$ \\ 1. Department of Naval Architecture and Marine Engineering, Bangladesh University of Engineering and Technology, Dhaka 1000, \\ Bangladesh \\ 2. Department of Port and Shipping Management, Bangabandhu Sheikh Mujibur Rahman Maritime University, Dhaka 1216, \\ Bangladesh
}

\begin{abstract}
Transportation cost is a significant part of the total manufacturing process. In order to achieve the cost advantage, it is imperative to reduce the transportation cost by facilitating seamless movement of goods. The transport infrastructure in Bangladesh is developing in a pace that might need a coordinated approach to facilitate a cost effective and smooth movement of goods. This paper has tried to provide a picture of the container transportation status, the potentiality of multimodalism, as well as the relative obstacle in Bangladesh. Moreover, to facilitate the multimodal transportation, the area of emphasis has been highlighted here. This paper aims to highlight the status, prospects and potentiality of multimodal transport in Bangladesh and the relative obstacles for its development.
\end{abstract}

Key words: Multimodalism, inland container terminal, inland water transport, sea port.

\section{Introduction}

MT (multimodal transport) means carriage of goods by at least two different modes under a single contract covering the door-to-door movements [1]. The advent of containerization has created the scope of modal transfer of cargo without the instances of intermediaries, leading towards the era of multimodal transport system, and has also enabled the shippers to take the advantage of transporting their cargo from their premises to the importers' door under the same contract. According to Muller [2], multimodal transport is "coordinated, seamless, flexible and continuous from door-to-door on two or more transportation modes". The MT system requires transport infrastructure, efficient operation, administration and legal framework, as well as efficient information exchange [3].

Corresponding author: Md. Mashiur Rahaman, assistant professor, research fields: computational fluid dynamics, marine transportation, dredging and ship recycling. E-mail: mashiurrahaman@name.buet.ac.bd.

\section{Transportation Status of Bangladesh}

Chittagong Port (whose location is shown in Fig. 1) is the gateway of all export-import of Bangladesh. Approximately $92 \%$ of export-import is handled by this port [4]. This port is well connected by road, rail and inland waterways to the capital Dhaka, the center of all economic activities. In the recent years, growing global trades of Bangladesh [5] have also achieved a competitive advantageous position of exporting goods in certain sectors like garments, knitwear, frozen food, medicine, and leather and jute products. For these industries, Bangladesh needs to import part of the raw materials from abroad. As a result, cargo handling in the Chittagong Port has increased remarkably. In the year of 2013, Bangladesh throughput in container handling was more than 1.5 million TEUs (Twenty-Foot Equivalent Units) [6]. The Chittagong Port has handled about 96\% and Mongla Port, which is the other sea-port in Bangladesh, has handled the rest. The locations of the two ports are shown in Fig. 1 [4]. Mongla Port is likely to handle more bulk commodities, 


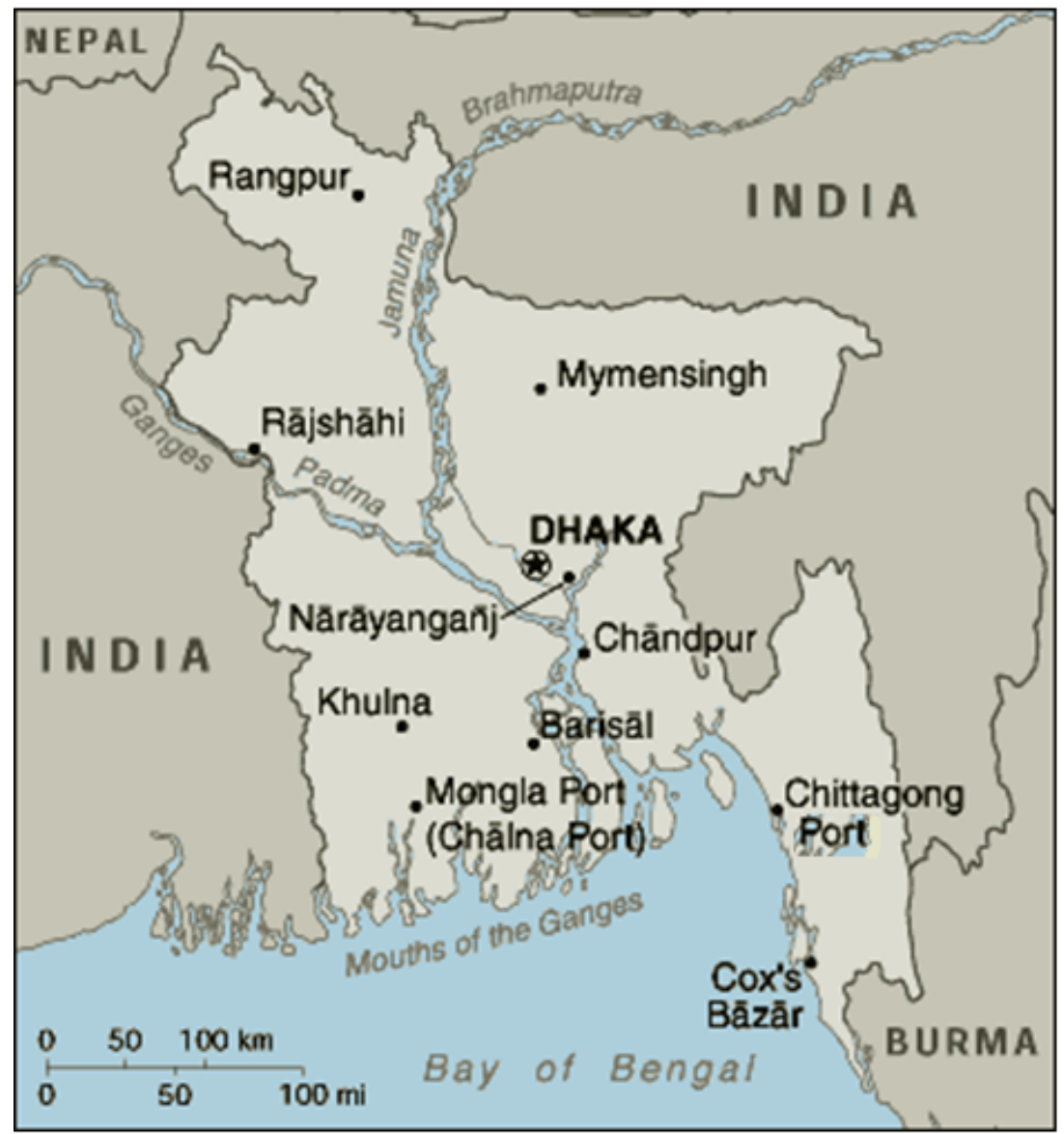

Fig. 1 Location of Chittagong Port and Mongla Port.

as road connectivity between the port and Dhaka is poor and there is no rail connectivity, either.

The hinterland distribution of containers from these two sea ports is almost completely dependent on the road. There is only one active ICD (Inland Container Depot) called the Dhaka ICD, which is connected through railway to Chittagong Port and this ICD can only handle about $5 \sim 7 \%$ of the total containers handled at the port [4].

Another ICD has been inaugurated in 2013 to transport the containers through inland waterways near Dhaka and Narayanganj, and this ICD has a handling capacity of 116,000 TEUs. However, till January 2015, this can manage to handle only 1,300 TEUs.

The latter ICD could facilitate both the sea ports as both the sea ports are well connected through IWT (Inland Water Transport) to this terminal. However, the output of this terminal is not satisfactory. As a result, the containers are transported by road and are mostly unpacked in Chittagong. This leads to excessive congestion on the road and also incurs extra monetary cost. Apart from water and land, some cargos from Bangladesh are transported by air (mostly to Middle East), and for this purpose, Dhaka International Air Port is used as the main hub.

Although Bangladesh has successfully achieved a position in international market, its transportation system has not attained reasonable improvement. The transportation cost has been reducing sharply in prospective countries. But in the case of Bangladesh, it has been rising sharply. For example, in 1970, the freight rate for jute from Bangladesh to Europe was $12.1 \%$ of the price, whereas in 2004 it was $27.6 \%$ and in 2007 even worse, rising to $44.2 \%$. On contrary, the transportation cost of rubber from Malaysia to Europe 
has reduced from $10.5 \%$ in 1970 to $6.5 \%$ in 2007 [7]. According to UNCTAD (United Nations Conference on Trade and Development) liner shipping connectivity index, which basically consider the countries' ships, services, TEU capacity deployed by companies, number of shipping companies, average and maximum ship size [8], Bangladesh ranked 104 in 2007 whereas in 2004 the rank was 116, which is a $23.2 \%$ improvement [7]. It is observed that the liner shipping connectivity index score of Bangladesh has increased from 5.2 in 2004 to 9.3 in 2015 , out of 100 [6]. That is, in a 10-years tenure, Bangladesh has managed to gain almost a doubled growth in the index. Therefore, it is observable that, although Bangladesh has gone far in the improvement in infrastructure and services, other aspects are still lagging behind.

There are four separate ministries that deal with the transportation matters of Bangladesh, which are the Ministry of Shipping, Ministry of Road Transport and Bridges, Ministry of Railways and Ministry of Civil Aviation and Tourism. Moreover, there are different parastatals and government agencies involved in different levels of planning, development, operation and control. At times, there is a lack of understanding in the policy making and planning process for integrating the transport system. Discrepancy among manufacturer in terms of privileges could also be found. For example, manufacturers in an EPZ (Export Processing Zone) are able to clear a standard 20-foot container within one day whereas manufacturers outside the zone need about nine days for custom clearance and another eight days in port for handling purpose [9]. Even though such kinds of privileges were being introduced to encourage foreign investment, there is a need to monitor or maintain a minimum standard for the other investors as well. Bangladesh has introduced the customs computer procedural system, called ASYCUDA (Automated System for Customs Data), to improve the efficiency of the ports (sea ports and ICT (Inland Container Terminal)) in terms of time required for handling the container.

Bangladesh has ratified the Carriage of Goods by Sea Rule (Hague Rule), 1925. Road and inland waterways followed the Carrier Act in 1865 to limit their loss of or damage to property delivered to them to be carried. The Bangladesh Railway, as a carrier, covers its liability under the Railway Act in 1890 [10]. It can be seen that legal harmony for integrating different transport modes is also required. The freight forwarders involved in such multimodal operation basically follow the UNCTAD/ICC rule, 1992, to conduct a contract.

\section{Prospect and Potential of Multimodal Transport}

On an average, container handling is increasing annually at a rate of $13 \%$ in the Chittagong Port and the CPA (Chittagong Port Authority) has taken necessary measures to cope with the increase. Mongla Port has also taken steps to increase the container handling share. Several measures have also been undertaken by the authorities to improve the hinterland connectivity.

Being a densely populated country, it is difficult to acquire more land for having wider roads and multiple railway tracks. However, physical works are underway to improve the Dhaka-Chittagong Railway into double track and Dhaka-Chittagong Highway to four lanes, which will obviously lead towards smooth and seamless hinterland connectivity in Bangladesh. Moreover, the construction of Padma Bridge will create huge opportunity since this bridge is going to connect the Mongla Port to Dhaka through both road and railway.

Being a riverine country, Bangladesh has better connectivity through IWT to the main seaports at Chittagong and Mongla. However, with a maximum share of transporting the bulk commodities to and from the seaport to different hinterland, container transportation has very slightly been developed in this sector. It is imperative that the transportation of 
containers also needs to divert in this sector as the limited railway and road infrastructure would not be able to bear much of it. Realizing the matter, several initiatives have been accepted both from the public, as well as private entities. Apart from the Pangaon ICT, the government is in a position to construct another ICT under Public-Private Partnership. The feasibility study on this project is underway. In addition to that, five private ICTs around Dhaka area are underway. The present status of these five ICTs has been furnished in Table 1.

The integration of transport activities along with all activities in the supply chain is the only way to achieve reduced delivery costs and times and improved services in competitive international markets [11]. As mentioned earlier, even though Bangladesh is progressing well to infrastructural and operational level, it is yet to achieve competitiveness in terms of transport cost. The reason is the lack of integration in the modal transformation. Therefore, there is a big potential to introduce the multimodal transport system in Bangladesh.

\section{The Obstacles and Bottlenecks}

The status part of this paper stated the obstacles and bottlenecks facilitating multimodalism in Bangladesh. Theoretically, lack of adequate infrastructure and policy is the main obstacle in the implementation of multimodalism.
Considering the six building blocks of determining the UNCTAD liner shipping connectivity index, the lack of a deep-sea port is the main concern here.

According to Ref. [12], there are six indicators that create differences in maritime freight, namely, distance, economy of scale, imbalance, types and values of goods, competition and port characteristics.

The availability of a deep-sea port could contribute in reducing the cost in several aspects. In Bangladesh, the ports are doing moderately well with number of ships calling, and the number of small shipping companies is also growing. However, the depth limit of the Chittagong Port constraints bigger vessel to call the port, blocking the big liners or global operators from investing into transportation system. In order to develop a sustainable door-to-door transport system, it is necessary to open the door for the international shipping and logistic companies, as well as for global port operators.

There is a need of good cooperation among the national and international transportation service providers. In addition to this, the hinterland connectivity also needs to get adequate importance. The scarcity of land obviously lead the country to transport more and more cargo through waterways, and the present state of transport investment shows that the public, as well as private sector, has given much emphasis in this area. But the pace of development is still far less than what is required and

Table 1 Status of ICT of Bangladesh.

\begin{tabular}{|l|l|l|l|l|l|}
\hline Terminal & $\begin{array}{l}\text { Planned capacity } \\
\text { (TEUs) }\end{array}$ & Land area & $\begin{array}{l}\text { Waterfront access } \\
\mathrm{m})\end{array}$ & $\begin{array}{l}\text { Expected date of } \\
\text { operation }\end{array}$ & Status of operations \\
\hline $\begin{array}{l}\text { SAPL (Summit } \\
\text { Alliance Port } \\
\text { Limited) }\end{array}$ & $\begin{array}{l}\text { Phase 1: 60,000 TEUs; } \\
\text { Phase 2: 60,000 TEUs }\end{array}$ & $\begin{array}{l}\text { Phase 1: 15.15 acres; } \\
\text { In the process of } \\
\text { acquiring 22 acres }\end{array}$ & $\begin{array}{l}215 \mathrm{~m} \\
\text { Phase 1: } 80 \mathrm{~m} ; \\
\text { Quay: 4.5 5 m } \\
\text { Draft alongside }\end{array}$ & 2015 & $\begin{array}{l}75 \% \text { complete } \\
\text { Phase } 1\end{array}$ \\
\hline Rupayan Group & $\begin{array}{l}\text { Phase 1: Full; } \\
375 \mathrm{~K} \text { TEU }\end{array}$ & $\begin{array}{l}\text { 30-acre Phase 1; } \\
\text { Additional land } \\
\text { acquired }\end{array}$ & $\begin{array}{l}2 \times 90 \mathrm{~m} \text { quay } \\
\text { Expansion }+90 \mathrm{~m}\end{array}$ & 2016 & $\begin{array}{l}\text { Approval granted } \\
\text { Land purchased } \\
\text { Design completed } \\
\text { Under construction } \\
\text { About 40\% complete }\end{array}$ \\
\hline Ak Khan Group & $\begin{array}{l}\text { 1st phase: 140,000; } \\
\text { 2nd phase: 70,000; } \\
\text { Final: 336,000 (in total) }\end{array}$ & $\begin{array}{l}\text { 1st phase: } 30 \text { acres; } \\
\text { In total 50 acres }\end{array}$ & $\begin{array}{l}\text { 1st phase: 2 jetties } \\
\text { with length of } 90 \mathrm{~m} \\
\text { each. }\end{array}$ & $\begin{array}{l}\text { Partial operation } \\
\text { September 2016 }\end{array}$ & $\begin{array}{l}\text { Approval granted } \\
\text { Land purchased } \\
\text { Land filling initiated } \\
\text { Design completed }\end{array}$ \\
\hline
\end{tabular}

Source: BIWTA (Bangladesh Inland Water Transport Authority), 2015. 
could improve substantially with more care from the government. As mentioned earlier, after the inauguration of Pangaon ICT and since December 2013 till now, only 1,300 TEUs have been cleared whereas it has an annual capacity of 116,000 TEUs. The less-than-capacity output has been subjected to discussions, and the lack of regular service has been identified as one of the problems. More than 30 service providers have been issued with license to operate ship to and from Chittagong and Pangaon, but none of them has started operation yet. The CPA has purchased three vessels but has not yet started regular liner service. Moreover, the shippers are still worried about the performance of IWT in transporting valuable cargos.

The national IMMTP (Integrated Multimodal Transport Policy) has been in force since 2013 and aims to build a secure, dependable and uninterrupted transport network addressing the relative problems in road, rail and inland waterways including the access to the sea and air ports. It is rather new and it will hopefully create some differences. Customs are considered as a significant part of import and export, and there are a lot of scopes to improve customs services in Bangladesh. The entrepreneurs think that, rather than infrastructural impediments, customs procedures and formalities in Bangladesh are more complex. The necessity of building bonded warehouses has been discussed for years as well. Introduction of EDI (Electronic Data Interchange) was also a main concern to transfer data among the biggest shipper and customs and port, impeding the development of multimodalism [11].

As Bangladesh does not have any uniform legal framework for the multimodalism, it needs to ratify an international convention. For the inland haulage after the sea leg, there is no internationally uniform liability limit for the service providers, which is also obstructing the growth of the insurance services for multimodal transport system.

\section{Areas that Need Emphasis in Order to Facilitate the Multimodal System}

If we sum up the above discussion, we can identify the significant areas that will facilitate the development of multimodal transport in Bangladesh. Firstly, infrastructural development should cover deep sea ports and seamless hinterland connectivity with emphasis on IWT terminals. Secondly, the commitment of the government is necessary to promote transport service, to generate professionalism and to add user-friendly interface in the customs procedures and formalities stage. Thirdly, emphasis on the use of information technology would be prerequisite for door-to-door transport.

\section{Conclusions}

In the era of globalization, cost reduction is essential to achieve competitive advantage in the manufacturing of goods. Transport cost is a significant part of a product in today's world of decentralizing of production process. Therefore, it is pertinent for least developed countries to introduce multimodal transport as a way of reducing intermediaries from the transport process, leading to the reduction of transport cost. Bangladesh is now competing in the international market of ready-made garments and knitwear with India, Pakistan, Vietnam, and to some extent with China. Now, Bangladesh could benefit from implementing multimodal transport solution, as it will lower transport cost compared to competitors and enhance timely delivery of goods.

\section{References}

[1] UNCTAD (United Nations Conference on Trade and Development). 1995. "Facing the Challenge of Integrated Transport Services.” UNCTAD. Accessed June 11, 2015. http://r0.unctad.org/en/subsites/multimod/mt2brf0.htm.

[2] Muller, G. 1999. Intermodal Freight Transportation. 4th ed. Washington, D.C.: Eno Transportation Foundation.

[3] Islam, D. M. Z., Dinwoodie, J., and Roe, M. 2005. “Towards Supply Chain Integration through Multimodal 
Transport in Developing Economies: The Case of Bangladesh.” Maritime Economics \& Logistics 7: 382-99.

[4] CPA (Chittagong Port Authority). "Location of Chittagong Port Authority." CPA. Accessed June 11, 2015. http://www.worldportsource.com/ports/BGD_Port_ of_Chittagong_2102.php.

[5] World Trade Organization. 2014. "International Trade Statistics 2014." World Trade Organization. Accessed June 17, 2015. https://www.wto.org/english/res_e/statis_e/ its2014_e/its2014_e.pdf

[6] UNCTAD (United Nations Conference on Trade and Development). 2009. "Review of Maritime Transport 2014.” New York and Geneva: UNCTAD. Accessed July 11, 2015. http://unctadstat.unctad.org/CountryProfile/050/ 050GeneralProfile.pdf.

[7] UNCTAD (United Nations Conference on Trade and Development). 2009. "Review of Maritime Transport 2008." New York and Geneva: UNCTAD. Accessed July 1, 2015. http://unctad.org/en/docs/rmt2008_en.pdf.

[8] UNCTAD (United Nations Conference on Trade and
Development). 2005. "UNCTAD Transport Newsletter." No. 29. Third Quarter. Geneva: UNCTAD. Accessed August 7, 2015. http://www.unctad.org/en/docs/sdtetlbmisc 20055_en.pdf.

[9] Hausman. W. H., Lee. H. L., and Subramanian. U. 2005. Global Logistics Indicators, Supply Chain Matrices, and Bilateral Trade Patterns. World Bank Policy Research Working Paper 3773, November. Washington, D.C.: World Bank.

[10] Ministry of Law. 1988. Bangladesh Code (English Ed.). Dhaka: Ministry of Law, Government of Bangladesh. Accessed August 21, 2015. http://bdlaws.gov.bd/ index.php?menu=about.

[11] Islam, D. M. Z., Dinwoodie, J., and Roe, M. 2006. "Promoting Development through Multimodal Freight Transport in Bangladesh." Transport Review 26: 571-91. Accessed August 19, 2015. http://www.tandfonline.com/ doi/abs/10.1080/01441640600576902.

[12] Hoffmann. J. 2009. Determinants of Transport Cost. Lecture handout, World Maritime University, Malmo, Sweden. (unpublished) 